\title{
Momilactones A and B: Optimization of Yields from Isolation and Purification
}

\author{
Truong Ngoc Minh 1 (iD), Tran Dang Xuan 1,* (i), Ateeque Ahmad ${ }^{2}$ (D), \\ Abdelnaser Abdelghany Elzaawely ${ }^{3}$ (D), Rolf Teschke ${ }^{4,5}$ and Truong Mai Van ${ }^{1}$ \\ 1 Graduate school for International Development and Cooperation (IDEC), Hiroshima University, \\ Hiroshima 739-8529, Japan; minhtn689@gmail.com (T.N.M.); truongmaivan1991@gmail.com (T.M.V.) \\ 2 Process Chemistry and Technology Department, Central Institute of Medicinal and Aromatic Plants, \\ Lucknow 226016, India; ateeque97@gmail.com \\ 3 Department of Agricultural Botany, Faculty of Agriculture, Tanta University, Tanta 31527, Egypt; \\ elzaawely@agr.tanta.edu.eg \\ 4 Department of Internal Medicine II, Division of Gastroenterology and Hepatology, Klinikum Hanau, \\ D-63450 Hanau, Germany; rolf.teschke@gmx.de \\ 5 Teaching Hospital of the Medical Faculty, Goethe University Frankfurt, D-60590 Frankfurt, Germany \\ * Correspondence: tdxuan@hiroshima-u.ac.jp; Tel./Fax: +81-82-424-6927
}

Received: 21 March 2018; Accepted: 7 May 2018; Published: 14 May 2018

\begin{abstract}
Momilactones A and B (MA and MB, respectively) are phytoalexins and plant growth inhibitors available in rice husks. However, to date, the isolation and purification of the two compounds have been complicated, laborious, and less effective. The present study was conducted to establish a protocol to simplify and optimize quantities of MA and MB by combinations of ethyl acetate (EtOAc), distilled water, methanol $(\mathrm{MeOH})$, temperature, and pressure for extractions. At a temperature of $100{ }^{\circ} \mathrm{C}$, combined with EtOAc and $\mathrm{MeOH} 100 \%$, MA and $\mathrm{MB}$ were enriched in greater quantities than non-treated rice husks, of which MB was much augmented than MA. The EtOAc extract obtained from samples dried at $100{ }^{\circ} \mathrm{C}$ for $1 \mathrm{~h}$, then placed in $\mathrm{MeOH} 100 \%$ for 1 week, provided maximum yields of MA [58.76 $\mu \mathrm{g} / \mathrm{g}$ dry weight (DW)] and MB (104.43 $\mu \mathrm{g} / \mathrm{g}$ DW). The use of pressure effectively enhanced yields of MA (17.90-26.26 $\mu \mathrm{g} / \mathrm{g}$ DW) and MB (40.78-71.0 $\mu \mathrm{g} / \mathrm{g} \mathrm{DW})$. The actual purified amounts of MA and MB increased by 5 and 15 folds, respectively. The use of either sole distilled water or $\mathrm{MeOH} \leq 50 \%$ at any temperature did not successfully isolate both MA and MB. The yield optimization aids to easier and more productive purification of the two compounds, and thus extends researches on biological activities of MA and MB, including pharmaceutical and medicinal properties.
\end{abstract}

Keywords: momilactone A; momilactone B; column chromatography; yield optimization; temperature; pressure; extracting solvents

\section{Introduction}

Rice husks are an agricultural waste that farmers have experienced difficulties disposing of in large quantities. However, rice husks are reported to be an effective source for weed management in crops [1-3]. Among plant growth inhibitors that have been detected in rice husks, such as phenolic acids, fatty acids, phenylalkanoic acids, hydroxyamic acids, terpenes, and indoles, momilactones A (MA) and B (MB) have showed a particular potency for controlling weed emergence [4,5]. Trials carried out in fields, greenhouses, and laboratories showed that MA and MB were promising for weed management [6-9]. Chemical structures of MA and MB are shown in Figure 1. 


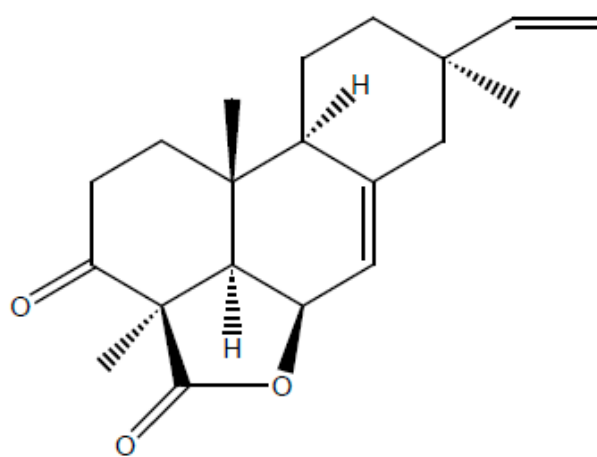

Momilactone A

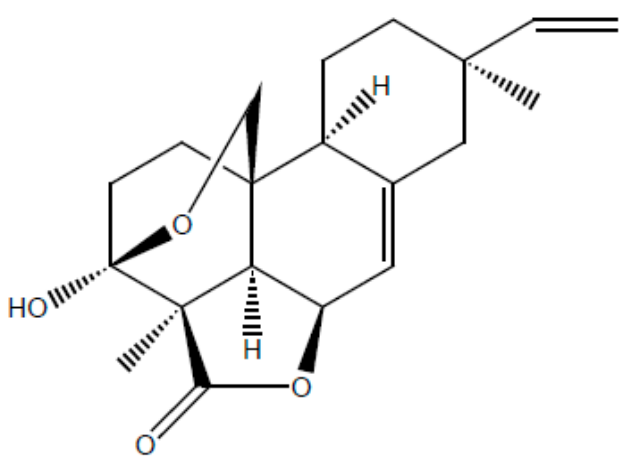

Momilactone B

Figure 1. Chemical structures of momilactone A (MA) and momilactone B (MB).

MA and MB were first identified and isolated from rice husks and it was reported that they caused inhibition on germination and root elongation of rice seedlings [10-12]. Momilactone is the combination of two words: momi means rice husk in Japanese, and the chemical structures of MA and $\mathrm{MB}$ are lactone (Figure 1). The two compounds were also found in rice leaves and straws and documented as phytoalexins [13-17]. Several analytical methods to identify and quantify MA and MB by reverse phase-high performance liquid chromatography (RP-HPLC) [18], thin layer chromatography and flame ionization detection (TLC/FID) [19], high-performance liquid chromatography-tandem mass spectrometry (HPLC-MS-MS) [20], thin layer chromatography (TLC) [21], chromatography mass spectrometry in the selected ion monitoring mode (GC-MS-SIM) [14], and gas chromatography-mass spectrometry (GC-MS) [8,22]; The uses of cold percolation and extracting solvents of either methanol $(\mathrm{MeOH})$ or $\mathrm{MeOH}-\mathrm{H}_{2} \mathrm{O}(8: 2 w / w)$ to isolate $\mathrm{MA}$ and $\mathrm{MB}$ have been reported $[11,12,23]$. However, the actual yields of MA and MB purified by column chromatography were low (MA: 0.8-15 $\mu \mathrm{g} / \mathrm{g}$; MB: $0.5-10 \mu \mathrm{g} / \mathrm{g}$ husks) $[10,12,23]$. Therefore, methods to enrich and optimize quantities of MA and $\mathrm{MB}$ in rice husks are needed.

Although phenolics play an important role in rice allelopathy [24], MA and MB showed a particular mode of action on plant inhibition [25]. MA and MB have been found only in rice plants and rice exudates, but they were also observed in the moss Hypnum plumaeforme [21,26], although the two plants are taxonomically quite distinct [26]. Besides allelopathy, MA and MB were recently reported to correlate to drought and salinity tolerance in rice [22]. MA and MB have been found in rice leaves, husks, straws, and root exudates $[14,20,25,27,28]$. The gene involved in the biosynthesis of MA has been identified in Echinochloa crus-galli [29]. Contents of MA and MB depended on rice varieties, growing stage, and extraction methods $[5,22,26,30]$. The use of high temperature in extraction, combined with relevant extracting solvents may effectively enrich yields of natural products [26].

In this study, the effectiveness of different extractions by using combination of distilled water, $\mathrm{MeOH}$, and ethyl acetate (EtOAc) combined with boiling and heating conditions, and pressure to optimize yields of MA and MB was examined.

\section{Materials and Methods}

\subsection{Preaparation of Rice Husks and Extracts}

An amount of $30 \mathrm{~kg}$ dried rice husks (subtype: Japonica; var. Koshihikari) were collected from rice mills in Saijo area, close to Hiroshima University, Higashi Hiroshima, Japan, in August 2017. The rice husks were ground to a fine powder and immersed in $\mathrm{MeOH} \mathrm{100 \%} \mathrm{for} 2$ weeks at room temperature. Then, this was concentrated under vacuum to produce an extract for isolation and purification of MA and MB. 


\subsection{Extraction and Isolation of $M A$ and $M B$}

The $\mathrm{MeOH}$ extract was diluted with $\mathrm{MeOH}$ again and mixed with activated charcoal $(2 \mathrm{~h})$ to remove chlorophylls and odors and filtered through a celite bed. By this step, no absorption of MA and $\mathrm{MB}$ was detected in the activated charcoal (data not shown). It was kept in a refrigerator for $4 \mathrm{~h}\left(5^{\circ} \mathrm{C}\right)$ to crystallize fat and filtered through filter papers. The supernatant was concentrated by a rotary evaporator. The obtained solid matrix was dissolved in $300 \mathrm{~mL}$ distilled water and sequentially partitioned with hexane, EtOAc. The yields of hexane ( $40 \mathrm{~g})$, EtOAc ( $350 \mathrm{~g})$, and aqueous $(80 \mathrm{~g})$, were achieved. The EtOAc extract was subjected to a normal-phase column chromatography [silica gel (70-230 mesh ASTM); LiChroprep RP-18 column (40-63 $\mu \mathrm{m})$ ] to yield 60 fractions, of which fractions 1-10 in hexane, fractions 11-20 in hexane:EtOAc (9.5:0.5), fractions 21-30 in hexane:EtOAc (9:1), fractions 31-50 in hexane:EtOAc (8:2), fractions 51-60 in hexane:EtOAc (7:3). After examination by TLC, fractions 35-50, were further subjected to a column chromatography over silica gel with chloroform:methanol $\left(\mathrm{CHCl}_{3}: \mathrm{MeOH}\right)(99: 1)$ to yield a mixture of MA and $\mathrm{MB}$. These mixtures were further purified by column chromatography over silica gel with $\mathrm{CHCl}_{3}: \mathrm{MeOH}$ (99.8:0.2; 99.6:0.4; 99.4:0.6; 99.2:0.8; 99.0:1.0) to successfully purify MA (350 mg) and MB (200 mg).

\subsection{Reagents and Analytical Instruments}

The solvents used for extraction of the rice husks were of analytical grade and purchased from Junsei Chemical Co., Ltd., Tokyo, Japan. The solvents used for HPLC analysis of the extracts as well as the standard chemicals were of HPLC grade and procured from Merck, Tokyo, Japan. The standard MA and MB were isolated in our laboratory as mentioned above at purity of $98 \%$ and $97 \%$, respectively. The solvents were filtered through a $0.45 \mu \mathrm{m}$ Millipore membrane (Millipore, Billerica, MA, USA) before injection into the HPLC. Digital melting point apparatus (Shambhavi Impex, Navi Mumbai, India) was used to determine melting points, whereas a Rudolf autopol model polarimeter was used for measurement of the optical rotations. Pre-coated TLC plates of thickness $0.25 \mathrm{~mm}$ and column chromatography filled with silica gel of 70-230 mesh ASTM and LiChroprep RP-18 (40-63 mm) were procured from Merck (Darmstadt, Germany). Visualization of the TLC spots was displayed by $5 \%$ $\mathrm{H}_{2} \mathrm{SO}_{4}$ in ethanol spray reagent. Both ${ }^{1} \mathrm{H}$ and ${ }^{13} \mathrm{C}$ nuclear magnetic resonance (NMR) spectra were obtained on a Brucker DRX-500 model spectrometer (Bruker India Scientific Pvt. Ltd., New Delhi, India) operated at 500 and $125 \mathrm{MHz}$, respectively. The NMR spectra were obtained in deuterated $\mathrm{CHCl}_{3}$ using tetramethylsilane (TMS) as an internal standard. The fast atom bombardment mass spectroscopy (FABMS) data were recorded on a JEOL SX- 102 spectrometer (JEOL USA Inc., Peabody, MA, USA) and electrospray ionization mass (ESI) in direct mass analysis of high performance liquid chromatography-photodiode array-mass spectrometry detectors (HPLC-PDA-MS) spectrometer (Shimadzu Corporation, Kyoto, Japan) and high-resolution mass spectrometry (HRMS) was measured on Agilent technology 6545Q-TOF LC/MS (5301 Stevens Dreek Blvd. Santa Clara, CA, USA). Infrared spectroscopy was recorded on a fourier transform infrared (FT-IR) spectrophotometer Shimadzu 8201 PC (4000-400 $\mathrm{cm}^{-1}$ ) (Shimadzu Cooporation, Kyoto, Japan).

\subsection{NMR Data of $M A$ and $M B$}

MA: Colourless crystalline compound; $\mathrm{R}_{\mathrm{f}} 0.48\left(\mathrm{CHCl}_{3}: \mathrm{MeOH} ; 9.5: 0.5\right)$; m.p. $234-236{ }^{\circ} \mathrm{C}$; IR $v_{\max }$ : 2936, 1766, 1698, 1637, 1390, 1188, 990, 908; ${ }^{1} \mathrm{H}$ NMR ( $\left.\mathrm{CDCl}_{3} ; 500 \mathrm{MHz}\right): \delta 1.90\left(\mathrm{~m}, \mathrm{H}_{2}-1 \alpha\right), 2.59-2.63$ (m, H-2), $2.31(\mathrm{~d}, J=5.0, \mathrm{H}-5), 4.84(\mathrm{t}, J=5.0, \mathrm{H}-6), 5.70(\mathrm{~d}, J=5.0, \mathrm{H}-7), 1.74-1.80(\mathrm{~m}, \mathrm{H}-9, \mathrm{H}-11 \alpha)$, $1.32\left(\mathrm{~m}, \mathrm{H}_{2}-11 \beta\right), 1.56-1.62$ (m, complex, $\left.\mathrm{H}_{2}-1 \beta, \mathrm{H}_{2}-12\right), 2.20,2.19$ (d, J = 12.5, $\left.\mathrm{H}_{2}-14\right), 5.84$ ( d d, J = 17.0, 11.0, H-15), 4.97, 4.93 (d d, J = 17.0 \& 1; 10.0 \& 1, H-16), 0.88 (s, H-17), 1.52 (s, H-18), 0.98 (s, H-20). ${ }^{13} \mathrm{C} \mathrm{NMR}\left(\mathrm{CDCl}_{3} ; 125 \mathrm{MHz}\right): \delta 34.89$ (C-1), 31.21 (C-2), 205.20 (C-3), 53.57 (C-4),46.46 (C-5), 73.17 (C-6), 114.03 (C-7), 148.96 (C-8), 50.18 (C-9), 32.46 (C-10), 23.99 (C-11), 37.24 (C-12), 40.13 (C-13), 47.53 (C-14), 148.03 (C-15), 110.17 (C-16), 21.80 (C-17), 21.47(C-18), 174.32 (C-19), 21.96 (C-20); HPLC-PDA-MS 
ESI $^{+}: 315\left[\mathrm{M}+\mathrm{H}^{+}\left(\mathrm{C}_{20} \mathrm{H}_{27} \mathrm{O}_{3}\right) ; \mathrm{ESI}^{-}: 313[\mathrm{M}-\mathrm{H}]^{-}\left(\mathrm{C}_{20} \mathrm{H}_{25} \mathrm{O}_{3}\right) ; \mathrm{HRMS} 315.1959[\mathrm{M}+\mathrm{H}]^{+}\right.$(calc for $\mathrm{C}_{20} \mathrm{H}_{27} \mathrm{O}_{3}$, 315.1960). (Compare NMR data with previous literature $\left.[10,11,13,18]\right)$.

MB: Colourless crystalline compound; $\mathrm{R}_{\mathrm{f}} 0.42\left(\mathrm{CHCl}_{3}: \mathrm{MeOH}\right.$; 9.5:0.5); m.p. $240{ }^{\circ} \mathrm{C}$; IR $v_{\text {max }}$ : 2920, 1737, 1662, 1637, 1461, 1296, 992, 916; ${ }^{1} \mathrm{H}$ NMR $\left(\mathrm{CDCl}_{3} ; 500 \mathrm{MHz}\right): \delta 1.99$ (m, H-1 $\left.\alpha\right), 2.13-2.06$ (m, complex H-2, H-14), 2.20 (dd, $J=6.5,2.0, \mathrm{H}-5), 4.97(\mathrm{t}, J=4.5, \mathrm{H}-6), 5.68(\mathrm{~d}, J=5.0, \mathrm{H}-7)$,

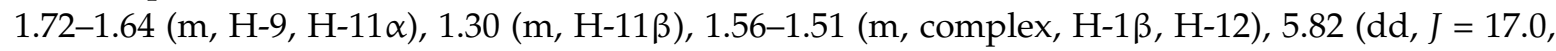
11.0, H-15), 4.93 (d d, J = 10.0 \& 1, H-16), 0.87 (s, H-17), 1.43 (s, H-18), 3.58, 4.07 (dd, 9.0, 3.1 7 9.0, 3.5).

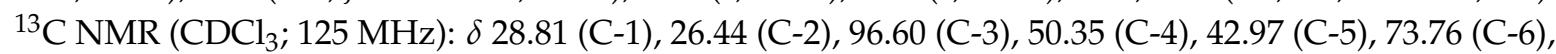
114.00 (C-7), 146.70 (C-8), 44.68 (C-9), 30.74 (C-10), 24.79 (C-11), 37.22 (C-12), 39.99 (C-13), 47.42 (C-14), 148.83 (C-15), 110.23 (C-16), 21.86 (C-17), 18.99 (C-18), 180.48 (C-19), 72.72 (C-20); HPLC-PDA-MS $\mathrm{ESI}^{+}: 331[\mathrm{M}+\mathrm{H}]^{+}\left(\mathrm{C}_{20} \mathrm{H}_{27} \mathrm{O}_{4}\right) ; \mathrm{ESI}^{-}: 329\left[\mathrm{M}-\mathrm{H}^{-}\left(\mathrm{C}_{20} \mathrm{H}_{25} \mathrm{O}_{4}\right) ; \mathrm{HRMS} 330.1905[\mathrm{M}+\mathrm{H}]^{+}\right.$(calc for $\left.\mathrm{C}_{20} \mathrm{H}_{27} \mathrm{O}_{4}, 315.1909\right)$, (compare NMR data with previous literature $\left.[10,11,13,18]\right)$.

\subsection{RP-HPLC and Separation Conditions}

The gradient liquid chromatographic system (model LC-10A series; Shimadzu, Tokyo, Japan) included two LC-10AD pumps controlled by a CMB-10A interface module, a model 7725i manual injector valve (Rheodyne) equipped with a $20 \mathrm{~mL}$ sample loop, and a multi-dimensional UV-Vis detector (model SPD-10A) (Shimadzu Europe, Duisburg, Germany). Data were collected and analyzed using a class LC-10. The workstation was equipped with an HP-DeskJet printer (Shimadzu Europe, Duisburg, Germany). The method involved the use of a Waters Spherisorb S10 ODS2 column $(250 \times 4.6 \mathrm{~mm}$, interior diameter (I.D.), 10 microm $)$ and binary gradient mobile phase profile. The extraction efficiency, peak purity and similarity were validated using a photo diode array detector, and a mobile phase consisting of $0.1 \%$ TFA in acetonitrile:water $(70: 30, v / v)$. The mobile phase was filtered through a $0.45 \mu \mathrm{m}$ Millipore filter and degassed by sonication for $30 \mathrm{~min}$. The flow rate

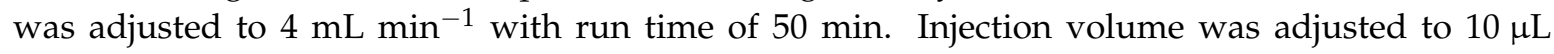
and detection was made at $210 \mathrm{~nm}$. Linearity was observed in the range of 10 to $250 \mu \mathrm{g} / \mathrm{mL}$, with correlation coefficients of MA and MB were 0.9936 and 0.9928 , respectively. Detection limit of MA was $0.9552 \mathrm{ng} / \mathrm{mL}$ and quantitation limit was $3.1840 \mathrm{ng} / \mathrm{mL}$. Detection limit of MB was $1.008 \mathrm{ng} / \mathrm{mL}$ and quantitation limit was $3.3617 \mathrm{ng} / \mathrm{mL}$ (Supplementary Material, Figure S1).

\section{6. $M A$ and $M B$ Enrichment}

An amount of $200 \mathrm{~g}$ of the dried rice husks were immersed in $1 \mathrm{~L}$ solvent and treated by different extractions as shown in Table 1, of which a different dilution of $\mathrm{MeOH}(10 \%, 30 \%, 50 \%, 70 \%$, and $100 \%)$ was conducted for 1 week (M1, M2, M3, M4, and M5, respectively) (Table 1). In similar manner, methods M6 and M7 included distilled water at room temperature and $100{ }^{\circ} \mathrm{C}$, respectively (Table 1 ). In the methods M8-M13, distilled water $\left(100^{\circ} \mathrm{C}\right)$ was used in different durations (30 min, $1 \mathrm{~h}, 2 \mathrm{~h}$, $3 \mathrm{~h}$, and $4 \mathrm{~h}$, respectively), and then immersed in either MeOH 100\% (M8, M10, M11, M12 and M13) or EtOAc (M9) for 1 week (Table 1). Various dilutions of $\mathrm{MeOH}(100 \%, 70 \%, 50 \%, 30 \%$ and 10\%) conducted in room temperature and boiled distill water were tested (M14-M20). Then the samples were dried by an oven at $100^{\circ} \mathrm{C}$ (SANYO Laboratory Convection Oven MOV-212F D, Sanyo Electric, Osaka, Japan) for $1 \mathrm{~h}$ (Table 1). The methods M21-M24 included the samples dried at $100{ }^{\circ} \mathrm{C}$ and boiled distilled water in 1-4 h, then placed in $\mathrm{MeOH} 100 \%$ (Table 1). The pressure (120 kPa) was applied, combined with either distilled water or dried (M25 and M26, respectively), followed by using $\mathrm{MeOH} 100 \%$ (Table 1). The obtained crude extracts were concentrated under reduced pressure at $30^{\circ} \mathrm{C}$, and dissolved in $100 \mathrm{~mL}$ distilled water and successively partition in hexane and ethyl acetate. The hexane supernatant was removed, and the ethyl acetate extract was kept in the dark at $5{ }^{\circ} \mathrm{C}$ for further analysis. 
Table 1. Yields of ethyl acetate (EtOAC) extract, MA and MB in different extractions.

\begin{tabular}{|c|c|c|c|c|}
\hline Methods & Codes & $\begin{array}{c}\text { EtOAc Crude } \\
\text { Extract (g) }\end{array}$ & MA ( $\mu \mathrm{g} / \mathrm{g}$ DW) & MB $(\mu \mathrm{g} / \mathrm{g}$ DW $)$ \\
\hline Controls (standards MA and MB by column chromatography) & M0 & 0.17 & $1.20 \pm 0.05^{j}$ & $0.70 \pm 0.03^{\mathrm{h}}$ \\
\hline $\mathrm{MeOH} 100 \%$ & M1 & 0.50 & $22.78 \pm 0.19$ ef & $42.80 \pm 8.76^{\text {cdef }}$ \\
\hline $\mathrm{MeOH} 70 \%$ & M2 & 0.46 & $38.35 \pm 3.08^{c}$ & $67.81 \pm 4.76^{\mathrm{bc}}$ \\
\hline $\mathrm{MeOH} 50 \%$ & M3 & 0.12 & nd & nd \\
\hline $\mathrm{MeOH} \mathrm{30 \%}$ & M4 & 0.10 & nd & nd \\
\hline $\mathrm{MeOH} 10 \%$ & M5 & 0.10 & nd & nd \\
\hline Distilled water (room temperature) & M6 & 0.04 & nd & nd \\
\hline Distilled water $\left(100^{\circ} \mathrm{C}\right)$ & M7 & 0.01 & nd & nd \\
\hline Distilled water $\left(100^{\circ} \mathrm{C}, 30 \mathrm{~min}\right)+\mathrm{MeOH} 100 \%$ & M8 & 0.67 & $18.54 \pm 1.77^{\mathrm{fg}}$ & $63.80 \pm 5.33^{\mathrm{cd}}$ \\
\hline Distilled water $\left(100{ }^{\circ} \mathrm{C}, 30 \mathrm{~min}\right)+$ EtOAc $100 \%$ & M9 & 0.50 & $21.27 \pm 1.38^{f}$ & $49.63 \pm 2.49$ cde \\
\hline Distilled water $\left(100{ }^{\circ} \mathrm{C}, 1 \mathrm{~h}\right)+\mathrm{MeOH} 100 \%$ & M10 & 0.45 & $28.83 \pm 0.03^{\mathrm{d}}$ & $3.02 \pm 0.02 \mathrm{~g}$ \\
\hline Distilled water $\left(100^{\circ} \mathrm{C}, 2 \mathrm{~h}\right)+\mathrm{MeOH} 100 \%$ & M11 & 0.50 & $51.54 \pm 0.95^{b}$ & $102.23 \pm 5.32^{a b}$ \\
\hline Distilled water $\left(100^{\circ} \mathrm{C}, 3 \mathrm{~h}\right)+\mathrm{MeOH} 100 \%$ & M12 & 0.50 & $21.78 \pm 0.79$ ef & $45.65 \pm 2.62^{\text {cdef }}$ \\
\hline Distilled water $\left(100^{\circ} \mathrm{C}, 4 \mathrm{~h}\right)+\mathrm{MeOH} 100 \%$ & M13 & 0.50 & $14.72 \pm 0.19 \mathrm{gh}$ & $30.65 \pm 1.38$ ef \\
\hline Dried $\left(100^{\circ} \mathrm{C}, 1 \mathrm{~h}\right)+\mathrm{MeOH} 100 \%$ & M14 & 0.45 & $58.76 \pm 3.75^{\mathrm{a}}$ & $104.43 \pm 6.44^{\mathrm{a}}$ \\
\hline Dried $\left(100^{\circ} \mathrm{C}, 1 \mathrm{~h}\right)+\mathrm{MeOH} 70 \%$ & M15 & 0.40 & $13.89 \pm 0.62 \mathrm{gh}$ & $29.68 \pm 1.89$ ef \\
\hline Dried $\left(100{ }^{\circ} \mathrm{C}, 1 \mathrm{~h}\right)+\mathrm{MeOH} 50 \%$ & M16 & 0.17 & nd & nd \\
\hline Dried $\left(100{ }^{\circ} \mathrm{C}, 1 \mathrm{~h}\right)+\mathrm{MeOH} 30 \%$ & M17 & 0.06 & nd & nd \\
\hline Dried $\left(100^{\circ} \mathrm{C}, 1 \mathrm{~h}\right)+\mathrm{MeOH} 10 \%$ & M18 & 0.20 & nd & nd \\
\hline Dried $\left(100^{\circ} \mathrm{C}, 1 \mathrm{~h}\right)+$ distilled water (room temperature) & M19 & 0.16 & nd & nd \\
\hline Dried $\left(100^{\circ} \mathrm{C}, 1 \mathrm{~h}\right)+$ distilled water $\left(100^{\circ} \mathrm{C}\right)$ & M20 & 0.62 & nd & nd \\
\hline Dried $\left(100^{\circ} \mathrm{C}, 1 \mathrm{~h}\right)$, distilled water $\left(100^{\circ} \mathrm{C}, 1 \mathrm{~h}\right)+\mathrm{MeOH} 100 \%$ & M21 & 0.31 & $15.03 \pm 0.51^{\mathrm{g}}$ & $14.04 \pm 0.33^{\mathrm{f}}$ \\
\hline Dried $\left(100^{\circ} \mathrm{C}, 2 \mathrm{~h}\right)$, distilled water $\left(100^{\circ} \mathrm{C}, 2 \mathrm{~h}\right)+\mathrm{MeOH} 100 \%$ & M22 & 0.50 & $11.76 \pm 0.64 \mathrm{hi}$ & $35.19 \pm 2.43$ def \\
\hline Dried $\left(100{ }^{\circ} \mathrm{C}, 3 \mathrm{~h}\right)$, distilled water $\left(100^{\circ} \mathrm{C}, 3 \mathrm{~h}\right)+\mathrm{MeOH} 100 \%$ & M23 & 0.60 & $28.56 \pm 0.09 \mathrm{~d}$ & $53.03 \pm 2.45^{\text {cde }}$ \\
\hline Dried $\left(100^{\circ} \mathrm{C}, 4 \mathrm{~h}\right)$, distilled water $\left(100^{\circ} \mathrm{C}, 4 \mathrm{~h}\right)+\mathrm{MeOH} 100 \%$ & M24 & 0.40 & $6.68 \pm 0.34^{\mathrm{i}}$ & $20.26 \pm 1.51^{\mathrm{f}}$ \\
\hline Distilled water $\left(100^{\circ} \mathrm{C}, 120 \mathrm{kPa}\right)+\mathrm{MeOH} 100 \%$ & M25 & 0.40 & $26.26 \pm 1.44$ de & $40.78 \pm 2.82^{\text {cdef }}$ \\
\hline Dried $\left(100{ }^{\circ} \mathrm{C}, 120 \mathrm{kPa}\right)+\mathrm{MeOH} 100 \%$ & M26 & 0.50 & $17.90 \pm 0.18^{\mathrm{fg}}$ & $71.00 \pm 6.14^{b c}$ \\
\hline
\end{tabular}

EtOAc: ethyl acetate; MA and MB: momilactones A and B, respectively; nd: not detected; Values with similar letters in each column are not significantly different $(p<0.05)$; Values are means $\pm \mathrm{SD}$ (standard deviation).

\subsection{Preparation of $M A, M B$, and Extracts for Quantification by HPLC}

The stock solution of $1.0 \mathrm{mg} / \mathrm{mL}$ ethyl acetate extract was prepared by dissolving the purified MA and MB in methanol. The prepared solution was sonicated for $5 \mathrm{~min}$. Sample solutions of the extracts as showed in Table 1 were also prepared at $1.0 \mathrm{mg} / \mathrm{mL}$ in methanol and analyzed. All the samples were filtered through $0.45 \mu \mathrm{m}$ Millipore membranes before injected to HPLC for identification and quantification of MA and MB.

\subsection{Statistical Analysis}

The data were analyzed by one-way ANOVA using the Minitab 16.0 software (Minitab Inc., State College, PA, USA) for Window. Upon significant differences, means were separated using Tukey's test at $p<0.05$ with three replications and expressed as means \pm standard deviation (SD).

\section{Results}

Results in Table 1 showed quantities of MA and MB in different extractions, and the relevant amount of the EtOAc extracts. Of which the controls were the actual amounts of MA and MB purified by column chromatography in this study $(1.20$ and $0.70 \mu \mathrm{g} / \mathrm{g} \mathrm{DW}$, respectively). It was showed that the use of dried $\left(100{ }^{\circ} \mathrm{C}, 1 \mathrm{~h}\right)$ and distilled water $\left(100^{\circ} \mathrm{C}, 2 \mathrm{~h}\right)$ combined with $\mathrm{MeOH}$ $100 \%$ provided maximum amounts of MA and MB (58.76 and 104.43, 51.54 and $102.23 \mu \mathrm{g} / \mathrm{g}$ DW, respectively), as compared to other extracting methods. The use of pressure set at $120 \mathrm{kPa}, 100{ }^{\circ} \mathrm{C}$, and distilled water $\left(100{ }^{\circ} \mathrm{C}, 30 \mathrm{~min}\right)$ combined with $\mathrm{MeOH} 100 \%$ produced the yields of $\mathrm{MB}$ from 63.80-71.00 $\mu \mathrm{g} / \mathrm{g}$ DW. Other extracting methods showed 20.26-53.03 $\mu \mathrm{g} / \mathrm{g}$ DW, while the combination of distilled water $\left(100{ }^{\circ} \mathrm{C}, 1 \mathrm{~h}\right)$ with $\mathrm{MeOH} 100 \%$ caused the lowest quantity of $\mathrm{MB}(3.02 \mu \mathrm{g} / \mathrm{g} \mathrm{DW})$ (Table 1). For MA, when the sample was dried at $100{ }^{\circ} \mathrm{C}$ for $4 \mathrm{~h}$ then put in the distilled water $\left(100{ }^{\circ} \mathrm{C}, 4 \mathrm{~h}\right)$, this resulted in the minimum amount of MA $(6.68 \mu \mathrm{g} / \mathrm{g} \mathrm{DW})$, whilst other extracting methods provided $11.76-38.35 \mu \mathrm{g} / \mathrm{g}$ DW. The use of pressure was effectively enhanced yields of

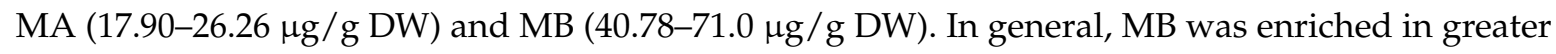


quantities than MA. It was observed that the use of distilled water only and $\mathrm{MeOH} \leq 50 \%$ at any temperature could successfully purify neither MA nor MB (Table 1, methods M3-M7, M16-M20).

\section{Discussion}

MA and MB were isolated from rice husks as plant growth inhibitors [5-7,10-13]. The chemical structure of $\mathrm{MB}$ was determined as 3,20-epoxy-3 $\alpha$-hydroxy-synpimara-7,15-dien-19,6 6 -olide, $\mathrm{C}_{20} \mathrm{H}_{26} \mathrm{O}_{4}$. Secretion of momilactone $B$ was later confirmed for other rice cultivars as well [30]. Besides this, MA (3-oxo-syn-pimara-7,15-dien-19,6 6 -olide, $\mathrm{C}_{20} \mathrm{H}_{26} \mathrm{O}_{3}$ ) was also found in the root exudates of rice (cv. Koshihikari) [31]. Both MA and MB were further found in various rice cultivars and origins $[8,22,32]$. To date, the biological activities of MA and MB have been limited to allelopathy, antioxidant, antifungal, and antimicrobial activities, although the cytotoxic and antitumor activity of $\mathrm{MB}$ on human colon cancer cell was reported [18]. The medicinal and pharmaceutical properties of MA and MB have not been much known, as the isolation and purification of MA and MB are complicated and laborious. There are only several laboratories worldwide have worked on MA and MB, and thus no standards of MA and MB can be purchased. This fact has prevented us from understanding the physiological roles of the two compounds in rice plants, and exploiting potential uses in medicines and pharmaceutics.

Table 2 shows the isolation and quantification of MA and MB which have been conducted so far by different analytical instruments, such as HPLC, LC-MS-MS, GC-MS, and GC-MS-SIM, which were applied to measure MA and MB in different parts of rice plants, seedlings, and root exudates. HPLC and TLC were useful in measuring contents of MA and MB in H. plumaeforme [21,26]. It is not known why rice and $H$. plumaeforme have quite distinct taxonomies, but they possess both MA and MB [21,26]. In this study, by column chromatography (CC), there were 1.2 and $0.7 \mu \mathrm{g} / \mathrm{g}$ DW of MA and $\mathrm{MB}$, respectively, which were purified. Comparing with other reports using CC to isolate MA and MB, they were similar to the yields conducted by Kato et al. [10] (0.8 and $0.5 \mu \mathrm{g} / \mathrm{g}$ DW, respectively) and Takahashi et al. [12] (1.0 and $0.8 \mu \mathrm{g} / \mathrm{g}$ DW, respectively). It is a fact that all of these Japanese researchers used similar rice varieties (cv. Koshihikari) as this study. In contrast, Chung et al. [23] achieved much higher quantities of MA and MB (15.0 and $10.0 \mu \mathrm{g} / \mathrm{g}$ DW, respectively) (Table 2), because they apparently used the husks of different rice cultivars in South Korea. In addition, the amounts of MA and MB may also be varied in CC techniques. In this study, the yields of both MA and MB were enriched up to 58.8 and $104.4 \mu \mathrm{g} / \mathrm{g}$ DW (Tables 1 and 2). Apparently, the quantities of MA and MB were much increased, and methods that used either rice husks dried $\left(100^{\circ} \mathrm{C}, 1 \mathrm{~h}\right)$, or boiled $\left(100{ }^{\circ} \mathrm{C}\right.$, $2 \mathrm{~h}$ ), then combined with $\mathrm{MeOH} 100 \%$ provided the maximum quantities of both MA and MB (Table 1). By GC-MS, Chung et al. [8] obtained yields of MA and MB in rice husks by 34.7 and $37.8 \mu \mathrm{g} / \mathrm{g}$ DW, respectively. However, the actual amounts purified by column chromatography were only 4.6 and $3.1 \mu \mathrm{g} / \mathrm{g}$ DW, respectively [15]. Thus, it can be seen that the authentic quantities of MA and MB were much less than their amounts estimated by GC-MS, approximately 7.5 and 12.2 folds. In comparison with the yields of MA and MB purified in this study (1.2 and $0.7 \mu \mathrm{g} / \mathrm{g}$ DW, respectively, Table 1), the theoretical volumes quantified by HPLC were 58.8 and $104.4 \mu \mathrm{g} / \mathrm{g}$ DW (Table 1), respectively, equivalent to approximately 50 and 150 folds, respectively. Thus, the certain extents of MA and MB after the enrichment which can be purified by CC may elevate to 5 and 15 folds.

Table 2 showed that, in previous research, different combinations among hexane, $\mathrm{EtOAc}, \mathrm{MeOH}$, and water were the most common solvents to extract MA and MB [6,8,10,15,20,21,23,28,30], although benzene [12] and $\mathrm{CHCl}_{3}$ [10] were also used. However, the use of either benzene or $\mathrm{CHCl}_{3}$ is not encouraged because of their toxicity. Temperature and pressure have been effective in optimizing yields of natural products, especially in industrial scale [33]. The replacement of $\mathrm{MeOH}$ by EtOH to reduce the hazardous possibility [34] during extraction of MA and MB should be also considered. In general, MA was found to be greater in quantity than MB in both rice and H. plumaeforme (Table 2). It was reported that, although MA had a greater amount in rice plant parts than $M B$, the biological activities, including allelopathy, antimicrobial and antioxidant activities of MB were stronger than 
MA $[15,22]$. However, in this study, by the treatment of temperature combined with pressure and different dilutions of $\mathrm{MeOH}, \mathrm{MB}$ was increased in much greater quantity than MA (Table 2).

Table 2. Contents of MA and MB in rice husks and rice plants

\begin{tabular}{|c|c|c|c|c|c|}
\hline MA ( $\mu \mathrm{g} / \mathrm{g}$ DW) & MB ( $\mu \mathrm{g} / \mathrm{g}$ DW) & Materials & Instruments & Extraction Protocols & References \\
\hline 15.0 & 10.0 & Rice husks & $\mathrm{CC}$ & Hexane:EtOAc (8:2) & [23] \\
\hline 4.6 & 3.1 & Rice husks & CC & Hexane:EtOAc (8:2) & [15] \\
\hline 4.5 & 3.0 & Rice straw & LC-MS-MS & EtOAc & [20] \\
\hline 4.9 & 2.9 & Rice husks & GC-MS & EtOAc: $\mathrm{H}_{2} \mathrm{O}(1: 1)$ & [8] \\
\hline 140.0 & 95.0 & Whole rice plants & HPLC & EtOAc & [6] \\
\hline $69.9-140.0$ & $64.4-114.1$ & Seedling * & GC-MS & EtOAc & [22] \\
\hline 0.8 & 0.5 & Rice husks & CC & $\mathrm{CHCl}_{2}+\mathrm{EtOH}$ & [10] \\
\hline nd & 245.0 & Rice shoots & HPLC & $\mathrm{MeOH}$ & [28] \\
\hline nd & 64.1 & Rice roots & HPLC & $\mathrm{MeOH}$ & [28] \\
\hline 80.6 & nd & Rice seeding & HPLC & MeOH: $\mathrm{H}_{2} \mathrm{O}(8: 2)$ & [30] \\
\hline 1.0 & 0.8 & Rice husks & CC & Benzene:EtOAc (10:1) & [12] \\
\hline 87.0 & 9.6 & UV-irradiated rice leaves & GC-MS-SIM & $\mathrm{MeOH}$ & [14] \\
\hline 34.7 & 37.8 & Rice husks & GC-MS & EtOAc: $\mathrm{H}_{2} \mathrm{O}(1: 1)$ & [8] \\
\hline 58.7 & 23.4 & Hypnum plumaeforme $\mathrm{L}$. & HPLC & EtOAc & [26] \\
\hline 8.4 & 4.2 & Hypnum plumaeforme $\mathrm{L}$. & TLC & EtOAc & {$[21]$} \\
\hline 1.2 & 0.7 & Rice husks & $\mathrm{CC}$ & Hexane:EtOAc (8:2) & $\begin{array}{l}\text { This study; For isolating } \\
\text { standard MA and MB }\end{array}$ \\
\hline $11.8-58.8$ & $3.0-104.4$ & Rice husks ${ }^{* *}$ & HPLC & $\begin{array}{c}\text { EtOAc; } \mathrm{MeOH} ; \\
\text { Temperature; Pressure }\end{array}$ & This study \\
\hline
\end{tabular}

nd: not detected; DW: dry weight; CC: column chromatography; HPLC: high performance liquid chromatography; GC-MS: gas chromatography mass spectrometry; GC-MS-SIM: gas chromatography mass spectrometry—selected ion monitoring; LC-MS-MS: liquid chromatography tandem mass spectrometric; TLC: thin layer chromatography; * Quantities varied among rice origins and subtypes; ** Quantities of MA and MB were enriched and varied among extractions.

The quantities of both MA and MB were enriched, although they varied among extractions (Table 1). Results in Table 1 noted that, although $\mathrm{MeOH}$ was an effective solvent in combination with EtOAc, temperature, and pressure, the use of either $\mathrm{MeOH} \leq 50 \%$ or distilled water only, at any temperature, could not successfully purify both MA and MB (Table 1). Although quantities of both MA and MB were enriched to 58.8 and $104.4 \mu \mathrm{g} / \mathrm{g}$ DW, respectively, they were in much lower amounts than other phytochemicals present in rice husks, such as phenolic acids and fatty acids.

In this study, the use of temperature was shown to be effective in quantity enrichment of both $\mathrm{MA}$ and $\mathrm{MB}$ (Tables 1 and 2). The treatment of temperature at $100{ }^{\circ} \mathrm{C}$ up to $3 \mathrm{~h}$ may affect the stability of both $\mathrm{MA}$ and $\mathrm{MB}$, and the degradation of natural products from plants can be influenced by high temperature, light, and microbes [35]. In this study, after treatment by temperatures, quantities of MA and MB were soon determined by HPLC and showed effective in optimizing yields of MA and MB (Table 1), but the stability of both MA and MB as well as other potent chemicals from rice husks should be further investigated.

As shown in Table 2, although the endogenous amounts of MA were generally higher than MB in rice husks, exudates, and other plant parts, the treatments of temperature at $100{ }^{\circ} \mathrm{C}$ was shown to be more effective in optimizing yields of MB than MA (Table 1). The melting point of $240^{\circ} \mathrm{C}$ of $\mathrm{MB}$ was higher than the $234-236^{\circ} \mathrm{C}$ of MA, which might not be crucial to explain why the yield of MB was greater than MA in this study. The synthesis of momilactones required temperature $>150{ }^{\circ} \mathrm{C}$ to achieve high yields [36]. The chemical structure of MB differs from MA by an oxygen bridge in a lactone ring (Figure 1) which might be more relevant to the superior efficacy from using high temperature to isolate $\mathrm{MB}$ as compared to MA, but this needs further elaboration. This study highlighted that $\mathrm{MeOH}$ was among the most productive, but the concentrations should not be $\leq 50 \%$, whilst water was not the ideal solvent to isolate and purify MA and MB (Table 1). It has been known that amounts of MA and MB largely varied among rice cultivars and origins [22], and thus the yields of MA and MB in husks of similar rice cultivar in Japan (cv. Koshihikari) in Kato et al. [10] and Takahashi et al. [12] and this study were compared. Firstly, by conventional protocol using column chromatography, we purified 1.2 and $0.7 \mu \mathrm{g} / \mathrm{g}$, and showed closed values as compared with Kato et al. [10] that successfully yielded 0.8 and 
$0.5 \mu \mathrm{g} / \mathrm{g}$, whereas Takahashi et al. [12] showed 1.0 and $0.8 \mu \mathrm{g} / \mathrm{g}$ MA and MB, respectively. However, by HPLC analysis, the quantities of MA and MB were theoretically optimized to $11.8-58.8 \mu \mathrm{g} / \mathrm{g}$ and 3.0-104.4 $\mu \mathrm{g} / \mathrm{g}$, respectively. The use of pressure did not approach the maximum yields of MA and MB in this study, but the optimized amounts were promising (MA: 17.90-26.26 $\mu \mathrm{g} / \mathrm{g}$ DW; MB: 40.78-71.0 $\mu \mathrm{g} / \mathrm{g}$ DW) (Table 1). This research provided practical information to efficiently purify greater quantities of MA and MB from rice husks to investigate further potent biological activities of the two compounds.

\section{Conclusions}

This study established a protocol to enrich and optimize quantities of MA and MB in rice husks by treatments with temperature and pressure, combined with extracting solvents of EtOAc and $\mathrm{MeOH}$. Amounts of MA and MB were strongly productive by treatments of $100{ }^{\circ} \mathrm{C}$, which may be due to their melting points of $234-236{ }^{\circ} \mathrm{C}$ and $240{ }^{\circ} \mathrm{C}$, respectively, although the stability of MA and MB after temperature treatment should be further examined. The application of pressure was effective to promote yields of MA and MB. The findings of this study assisted the purification of MA and MB in rice husks more effectively to exploit further biological activities of the two compounds, such as medicinal and pharmaceutical properties.

Supplementary Materials: The following are available online at http:/ / www.mdpi.com/2297-8739/5/2/28/s1, Figure S1: HPLC chromatogram of MA $(18.696 \pm 0.157 \mathrm{~min})$ and MB (15.037 $\pm 0.120 \mathrm{~min})$ measured at $210 \mathrm{~nm}$.

Author Contributions: T.N.M. and T.D.X. conceived the idea and wrote the manuscript. A.A. confirmed the chemical structures of momilactones A and B. A.A.E., T.M.V., and R.T. revised the manuscript.

Funding: This research received no external funding.

Acknowledgments: The authors appreciate Kobayashi International Scholarship Foundation to provide Truong Ngoc Minh a scholarship.

Conflicts of Interest: The authors declare no conflict of interest.

\section{References}

1. Khanh, T.D.; Chung, M.I.; Xuan, T.D.; Tawata, S. The exploitation of crop allelopathy in sustainable agricultural production. J. Agron. Crop Sci. 2005, 191, 172-184. [CrossRef]

2. Xuan, T.D.; Tsuzuki, E.; Terao, H.; Matstuo, M.; Khanh, T.D.; Murayama, S.; Hong, N.H. Alfalfa, rice by-products and their incorporation for weed control in rice. Weed Biol. Manag. 2003, 3, 137-144. [CrossRef]

3. Xuan, T.D.; Shinkichi, T.; Khanh, T.D.; Min, C.M. Biological control of weeds and plant pathogens in paddy rice by exploiting plant allelopathy: An overview. Crop Prot. 2015, 24, 197-206. [CrossRef]

4. Lee, C.-W.; Yoneyama, K.; Takeuchi, Y.; Ryu, S.N. Quantification of momilactones A and B in rice straw. Korean J. Crop Sci. 2002, 47, 283-285.

5. Kato-Noguchi, H.; Ino, T.; Kujime, H. The relation between growth inhibition and secretion level of momilactone B from rice root. J. Plant Interact. 2010, 5, 87-90. [CrossRef]

6. Kato-Noguchi, H.; Ota, K.; Ino, T. Release of momilactone A and B from rice plants into the rhizosphere and its bio-activities. Allelopathy J. 2008, 22, 321-328.

7. Kato-Noguchi, H.; Ino, T.; Ota, K. Secretion of momilactone A from rice roots to the rhizosphere. J. Plant Physiol. 2008, 165, 691-696. [CrossRef] [PubMed]

8. Chung, I.M.; Hahn, S.J.; Ahmad, A. Evaluation of allelopathic potential and quantification of momilactone A, $\mathrm{B}$ from rice hull extracts and assessment of inhibitory bioactivity on paddy field weeds. J. Agric. Food Chem. 2006, 54, 2527-2536. [CrossRef] [PubMed]

9. Toyomatsu, T.; Kagahara, T.; Odaka, K.; Koga, J.; Hasegawa, M.; Mitsuhashi, W.; Sassa, T.; Yamane, H. Diterpene phytoalexins are biosynthesized in and exudated from roots of rice seedlings. Biosci. Biotechnol. Biochem. 2008, $72,563-567$.

10. Kato, T.; Kabuto, C.; Sasaki, N.; Tsunagawa, M.; Aizawa, H.; Fujita, K.; Kato, Y.; Kitahara, Y. Momilactones, growth inhibitors from rice, Oryza sativa L. Tetrahedon Lett. 1973, 39, 3861-3864. [CrossRef] 
11. Kato, T.; Tsunakawa, M.; Sasaki, N.; Aizawa, H.; Fujita, K.; Kitahara, Y.; Takahashi, N. Growth and germination inhibitors in rice husk. Phytochemistry 1977, 16, 45-48. [CrossRef]

12. Takahashi, N.; Kato, T.; Tsunagawa, M.; Sasaki, N.; Kitahara, Y. Mechanisms of dormancy in rice seeds. II. New growth inhibitors, momilactone-A and -B isolated from the hulls of rice seeds. Jpn. J. Breed. 1976, 26, 91-98. [CrossRef]

13. Cartwright, D.W.; Langcake, P.; Pryce, R.J.; Leworthy, D.P.; Ride, J.P. Isolation and characterization of two phytoalexins from rice as momilactones A and B. Phytochemistry 1981, 20, 535-537. [CrossRef]

14. Kodama, O.; Suzuki, T.; Miyakawa, J.; Akatsuka, T. Ultraviolet induced accumulation of phytolexins in rice leaves. Agric. Biol. Chem. 1988, 52, 2469-2473.

15. Fukuta, M.; Xuan, T.D.; Deba, F.; Tawata, S.; Khanh, T.D.; Chung, I.M. Comparative efficacies in vitro of antibacterial, fungicidal, antioxidant, and herbicidal activities of momilatones A and B. J. Plant Interact. 2007, 2, 245-251. [CrossRef]

16. Okada, A.; Shimizu, T.; Okada, K.; Kuzuyama, T.; Koga, J.; Shibuya, N.; Noriji, H.; Yamane, H. Ecilitor induced activation of the methyerythritol phosphate pathway toward phytoalexins biosynthesis in rice. Plant Mol. Biol. 2007, 65, 177-187. [CrossRef] [PubMed]

17. Hasegawa, M.; Mitsuhara, I.; Seo, S.; Imai, T.; Koga, J.; Okada, K.; Yamane, H.; Ohashi, Y. Phytoalexin accumulation in the interaction between rice and the plant fungus. Mol. Plant Microbe Intract. 2010, 23, 1000-1011. [CrossRef] [PubMed]

18. Kim, S.J.; Park, H.R.; Park, E.; Lee, S.C. Cytotoxic and antitumor activity of momilactone B from rice hulls. J. Agric. Food Chem. 2007, 55, 1702-1706. [CrossRef] [PubMed]

19. Saha, P.K.; Hatakeda, K.; Kato, T. A convenient method for analysis of momilactones. Jpn. J. Crop Sci. 1981, 50, 382-387. [CrossRef]

20. Lee, C.W.; Yoneyama, K.; Takeuchi, Y.; Konnai, M.; Tamogami, S.; Kodama, O. Momilactones A and B in rice straw harvested at different growth stages. Biosci. Biotechnol. Biochem. 1999, 63, 1318-1320. [CrossRef] [PubMed]

21. Nozaki, H.; Hayashi, K.; Nishimura, N.; Kawaide, H.; Matsuo, A.; Takaoka, D. Momilactone A and B as allelochemicals from moss Hypnum plumaeforme: First occurrence in bryophytes. Biosci. Biotechnol. Biochem. 2007, 71, 3127-3130. [CrossRef] [PubMed]

22. Xuan, T.D.; Minh, T.N.; Anh, L.H.; Khanh, T.D. Allelopathic momilactones A and B are implied in rice drought and salinity tolerance, not weed resistance. Agron. Sustain. Dev. 2016, 36, 52. [CrossRef]

23. Chung, I.M.; Hahn, S.J.; Ahmad, T. Confirmation of potential herbicidal agents in hull of rice Oryza sativa. J. Chem. Ecol. 2005, 31, 1339-1352. [CrossRef] [PubMed]

24. Li, Z.-H.; Wang, Q.; Ruan, X.; Pan, C.-D.; Jiang, D.-A. Phenolics and plant allelopathy. Molecules 2010, 15, 8933-8952. [CrossRef] [PubMed]

25. Kato-Noguchi, H.; Peters, R.J. The role of momilactones in rice allelopathy. J. Chem. Ecol. 2013, 39, $175-185$. [CrossRef] [PubMed]

26. Kato-Noguchi, H.; Kobayashi, K.; Shigemori, H. Allelopathy of the moss Hypnum plumaeforme by the production of momilactones A and B. Weed Res. 2009, 49, 621-627. [CrossRef]

27. Grosso, C.; Valentão, P.; Ferreres, F.; Andrade, P.B. Alternative and efficient extraction methods for marine-derived compounds. Mar. Drugs. 2015, 13, 3182-3230. [CrossRef] [PubMed]

28. Cartwright, D.W.; Langcake, P.; Pryce, R.J.; Leworthy, D.P.; Ride, J.P. Chemical activation of host defense mechanisms as a basis for crop protection. Nature 1977, 267, 511-513. [CrossRef]

29. Guo, L.; Qiu, J.; Ye, C.; Jin, G.; Mao, L.; Zhang, H.; Yang, X.; Peng, Q.; Wang, Y.; Jia, L.; et al. Echinochloa crus-galli genome analysis provides insight into its adaptation and invasiveness as a weed. Nat. Commun. 2017, 8, 1031. [CrossRef] [PubMed]

30. Kato-Noguchi, H.; Ino, T. Rice seedlings release momilactone B into the environment. Phytochemistry 2003, 63, 551-554. [CrossRef]

31. Kato-Noguchi, H.; Ino, T. Possible involvement of momilactone B in rice allelopathy. J. Plant Physiol. 2005, 162, 718-721. [CrossRef] [PubMed]

32. Kong, C.H.; Liang, W.J.; Xu, X.H.; Hu, F. Release and activity of allelochemicals from allelopathic rice seedling. J. Agric. Food Chem. 2004, 52, 2861-2865. [CrossRef] [PubMed]

33. Mottaleb, M.A.; Sarker, S.D. Accelerated solvent extraction for natural products isolation. Methods Mol. Biol. 2012, 864, 75-87. [PubMed] 
34. Duereh, A.; Sato, Y.; Smith, R.L.; Inomata, H. Replacement of hazardous chemicals used in engineering plastics with safe and renewable-bond donor and acceptor solvent-pair mixtures. ACS Sustain. Chem. Eng. 2015, 3, 1881-1889. [CrossRef]

35. Castro, R.O.; Contreras, H.A.C.; Rodriguez, L.M.; Bucio, J.L. The role of microbial signals in plant growth and development. Plant Signal. Behav. 2009, 4, 701-712. [CrossRef]

36. Germain, J.; Deslongchamps, P. Total synthesis of ( \pm )-momilactone A. J. Org. Chem. 2002, 67, 5269-5278. [CrossRef] [PubMed] 